\title{
Cloning and characterization of the thiD/J gene of Escherichia coli encoding a thiamin- synthesizing bifunctional enzyme, hydroxymethylpyrimidine kinase/phosphomethylpyrimidine kinase
}

\author{
Tomoko Mizote, ${ }^{1,2}$ Masataka Tsuda, ${ }^{3}$ D. D. S. Smith, ${ }^{4}$ Hideo Nakayama ${ }^{1}+$ \\ and Teruko Nakazawa ${ }^{2}$
}

Author for correspondence: Tomoko Mizote. Tel: +8183928 2489. Fax: +81839282251.

e-mail:mizote@ws1.yamaguchi-pu.ac.jp

\footnotetext{
1 Department of Food and Nutrition, Yamaguchi Prefectural University, Sakurabatake, Yamaguchi 753-8502, Japan

2 Department of Microbiology, Yamaguchi University School of Medicine, Ube 755-8505, Japan

3 Institute of Genetic Ecology, Tohoku University, Katahira, Sendai 980-8577, Japan

4 Department of Food Macromolecular Science, Institute of Food Research, Earley Gate, Whiteknights Road, Reading RG6 6BZ, UK
}

\begin{abstract}
A $1.7 \mathrm{~kb}$ DNA fragment isolated from an $E$. coli genomic library was able to complement the thiamin requirement of strains carrying the thiM, thiJ and thiD mutations. The three genes encode hydroxyethylthiazole kinase, hydroxymethylpyrimidine (HMP) kinase and phosphomethylpyrimidine (HMP. P) kinase, respectively. Sequence analysis revealed that the $1.7 \mathrm{~kb}$ fragment contained two ORFs of 708 bp and 801 bp. The former ORF complemented the thiM mutation and the latter ORF both the this and thiD mutations. The latter ORF was cloned into the expression vector PET3a, and the encoded protein was purified through three successive column chromatographies. The purified protein was able to convert HMP to its monophosphate and the monophosphate to its pyrophosphate. These results suggest that the two distinct enzyme activities, HMP kinase and HMP-P kinase, are indeed a bifunctional enzyme encoded by a single gene, designated thiDIJ.
\end{abstract}

Keywords: Escherichia coli, hydroxymethylpyrimidine kinase, thiamin biosynthesis, bifunctional enzyme

\section{INTRODUCTION}

In the de novo synthesis of thiamin pyrophosphate (thiamin-PP) in Escherichia coli, reactions proceed through the independent formation of two heterocyclic intermediates, hydroxymethylpyrimidine pyrophosphate (HMP-PP) and hydroxyethylthiazole monophosphate (HET-P) with their subsequent coupling; the condensation gives rise to thiamin monophosphate (thiamin-P), an immediate precursor of thiamin-PP (Fig.

\footnotetext{
†Present address: Department of Internal Medicine, Sea-Side Hospital, Maruo, Higashikiwa, Ube 755-0241, Japan.

Abbreviations: HET, 4-methyl-5-( $\beta$-hydroxyethyl)-thiazole; HMP, 2methyl-4-amino-5-(hydroxymethyl)-pyrimidine; IMAC, immobilized-metal affinity chromatography; PAL, pyridoxal; -P, monophosphate; -PP, pyrophosphate; PIN, pyridoxine.

The DDBJ accession numbers for the thiD and thiM genes reported in this paper are D84200 and D88442, respectively.
}

1). When hydroxymethylpyrimidine (HMP) and hydroxyethylthiazole (HET) are supplied exogenously, they are taken up by the cell, phosphorylated, and converted to thiamin-PP by the de novo synthetic pathway. HMP$\mathrm{PP}$ is formed from HMP via the intermediate formation of hydroxymethylpyrimidine monophosphate (HMPP). Two distinct enzymes, HMP kinase and HMP-P kinase have been reported to catalyse the stepwise phosphorylation of HMP (Kawasaki et al., 1968). Our previous studies showed that mutations in the thiJ, thiD and thiM loci, leading to the inactivation of HMP kinase, HMP-P kinase and HET kinase, respectively, are located very close together on the chromosome at about 46 min (Mizote \& Nakayama, 1989b; Mizote et al., 1996).

In the course of these studies, we have found that pyridoxal (PAL) kinase (EC 2.7.1.35, $p d x L$ gene) also catalyses the phosphorylation of HMP to HMP-P 


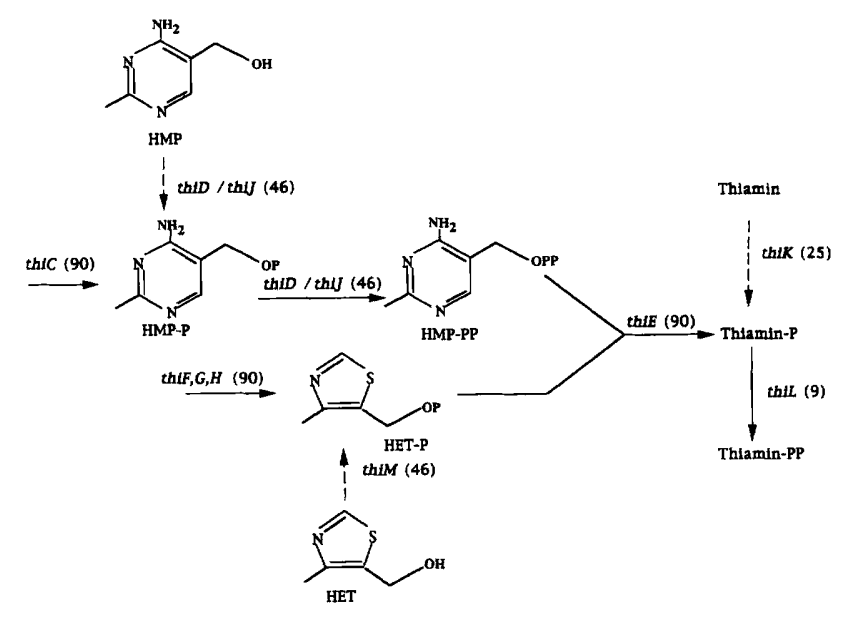

Fig. 1. Phosphorylation of HMP and HET in the biosynthesis of thiamin-PP in $E$. coli. The thiB locus was originally assumed to define the structural gene for thiamin-P synthetase (Kawasaki et al., 1968) but a strain carrying mutations in the locus was later shown to be complemented by clones carrying both thiF and thiG (Horn et al., 1993). More recently, thiE was identified as the gene encoding thiamin-P synthetase and was shown to be contained in the main operon at 90 min (Backstrom et al., 1995). Parentheses show approximate map positions (min) of each of the genes. Broken lines indicate salvage pathways.

(Mizote \& Nakayama, 1989a) and that the inactivation of both the $p d x L$ and thiJ genes in the same cell resulted in the complete loss of HMP kinase activity (Nakayama, 1990; Mizote et al., 1996).

In this paper we have re-examined the properties of a thiD mutant, NI500, which was reported to lack HMPP kinase activity (Imamura \& Nakayama, 1981) and found that a thiD $p d x L$ double mutant lacked not only HMP-P kinase but also HMP kinase activities. We also provide molecular-genetic evidence showing that an $E$. coli $1.7 \mathrm{~kb}$ chromosomal DNA fragment, which contains two ORFs, is able to complement the thiJ, thiD and thiM mutations. One ORF complements the thiM mutation, while the other complements both the thiJ and thiD mutations. A protein encoded by the latter ORF proved to catalyse two phosphorylation reactions: HMP to HMP-P and HMP-P to HMP-PP. These results suggest that HMP kinase and HMP-P kinase are encoded by a single gene previously designated either thiJ or thiD.

\section{METHODS}

Bacteria, plasmids and media. Bacterial strains and plasmids used in this study are listed in Table 1. Minimal medium 56 modified by Low (1973) was used as a basal medium. For P1 transduction, thiamin, pyridoxal (PAL) and PIN were added at 20,100 and $100 \mathrm{nM}$, respectively, as required. Luria broth (LB) was used for other experiments. Ampicillin, chloramphenicol and kanamycin were added to the medium at 100 , 30 and $50 \mu \mathrm{g} \mathrm{ml}^{-1}$, respectively.

Genetic manipulation. P1 transductions were carried out by the methods described by Lennox (1955) and Taylor \& Trotter (1967). DNA manipulations were carried out by the procedures of Sambrook et al. (1989). Tn1722 (Ubben \&
Schmit, 1986) loaded on pMT1282 was used for transposon mutagenesis as described previously (Tsuda \& Iino, 1987). PCR was performed using the touch-down method as described by Don et al. (1991) with primers designed as follows: F1 $\left(5^{\prime}\right.$ CATATGACCAATGATGTGGTGC $\left.3^{\prime}\right)$ and R1 $\left(5^{\prime}\right.$ GGATCCTCATGCCTCACCTCC $\left.3^{\prime}\right)$ for ORF1 and F2 (5' CATATGAAACGAATTAACGCTCTGACG $3^{\prime}$ ) and R2 (5' GGATCCTCACCACCAGGCGTGGAAGTGG 3') for ORF2. Complementation of each thi gene was assessed by using three thi mutant strains, SN164L-1 (thiM), SN372L-3-910 (thiJ) and NI500 (thiD). Strains with various plasmids carrying the thi region were tested for growth at $37^{\circ} \mathrm{C}$ on minimal medium containing the required amino acid supplements either with or without $20 \mathrm{nM}$ each of HET or HMP.

Growth of $E$. coli and preparation of cell-free extracts. E. coli strain BL21(DE3)(pLysS) was transformed with pTRD63 carrying ORF2. A $40 \mathrm{ml}$ portion from an overnight culture of the cells was inoculated into a 2 I culture of LB. When the cell count reached $3 \times 10^{7}$ cells $\mathrm{ml}^{-1}$, IPTG was added to a final concentration of $0.08 \mathrm{mM}$ and the culture was incubated for a further $2 \mathrm{~h}$. The cells were harvested by centrifugation, washed with $20 \mathrm{mM}$ Tris/ $\mathrm{HCl}$ buffer, $\mathrm{pH} 7 \cdot 5$, and lysed by French pressing at a cell pressure of 16000 p.s.i. (110.4 MPa). Unbroken cells and cell debris were eliminated by centrifugation for $60 \mathrm{~min}$ at 20000 r.p.m. using a Sorvall SS-34 rotor and the cell-free extract $(65 \cdot 1 \mathrm{ml})$ was obtained.

Purification of the thiD product. The thiD product was purified from the cell-free extracts using the following three successive chromatography steps.

Step 1: Chromatography on HiTrap Q. The cell-free extract $(21.7 \mathrm{ml})$ was loaded onto a HiTrap $Q$ column $(5 \mathrm{ml}$, Pharmacia) which had been equilibrated with $50 \mathrm{ml} 20 \mathrm{mM}$ Tris $/ \mathrm{HCl}, \mathrm{pH} 7 \cdot 5$. Then the column was washed with $10 \mathrm{ml}$ starting buffer, and proteins were eluted with a $40 \mathrm{ml}$ linear gradient of $\mathrm{NaCl}(0-0.4 \mathrm{M})$ in the same buffer at a flow rate of $4 \mathrm{ml} \mathrm{min}{ }^{-1}$. Fractions having the HMP-phosphorylating activity with an $A_{280}$ over 0.1 were pooled and dialysed against $2.5120 \mathrm{mM}$ MOPS buffer containing $0.2 \mathrm{M} \mathrm{NaCl}, \mathrm{pH} 7.0$ (buffer A). The rest of the cell-free extract $(43.4 \mathrm{ml})$ was similarly purified and combined.

Step 2: Immobilized-metal affinity chromatography (IMAC). The preparation obtained in step 1 was applied to a Ni-affinity column ( $1 \mathrm{ml}$, Pharmacia) which had been pre-equilibrated with buffer A. The column was washed with $2.5 \mathrm{ml}$ buffer A and eluted with a $20 \mathrm{ml}$ linear gradient of imidazole $(0-50 \mathrm{mM})$ in buffer $A$ at a flow rate of $1 \mathrm{ml} \mathrm{min}^{-1}$ and the active fractions were collected. Active fractions were pooled and dialysed against $2120 \mathrm{mM}$ Tris/ $\mathrm{HCl}$ buffer, $\mathrm{pH} 8.0$.

Step 3: Mono Q chromatography. The preparation obtained in Step 2 was applied to a Mono-Q HR5/5 column $(1 \mathrm{ml}$, Pharmacia) which had been pre-equilibrated with $20 \mathrm{mM}$ Tris/ $\mathrm{HCl}$, pH 8.0, containing $0.5 \mathrm{mM}$ DTT (buffer B). Prior to application, DTT was added to the sample to a final concentration of $0.5 \mathrm{mM}$. After application of the sample, the column was washed with $5 \mathrm{ml}$ buffer $B$ and then eluted with a $16 \mathrm{ml}$ linear gradient of $\mathrm{NaCl}(0-0.4 \mathrm{M})$ at a flow rate of $1 \mathrm{ml} \mathrm{min}{ }^{-1}$. The active fractions were pooled and stored at $-20^{\circ} \mathrm{C}$ after the addition of $20 \%(\mathrm{v} / \mathrm{v})$ glycerol.

Characterization of the purified enzyme. SDS-PAGE was carried out on a $10-20 \%$ gradient gel of Tris-Tricine (Novex) and the gel was stained with Coomassie blue. Isoelectricfocusing electrophoresis was carried out on a polyacrylamide gel (IEF-PAGE, pH 3-10; Novex) and run as recommended by 
Table 1. E. coli strains and plasmids

\begin{tabular}{|c|c|c|c|}
\hline Strain or plasmid & Relevant genotype ${ }^{*}$ & $\begin{array}{c}\text { Relevant } \\
\text { phenotype }\end{array}$ & Source $\neq$ \\
\hline \multicolumn{4}{|l|}{ Bacterial strains } \\
\hline JC1552 & argG6 metB1 his-1 leu-6 trp-31 rpsL104 & & CGSC \\
\hline SN372L-3-9-10 & JC1552, thiC pdxB20 pdxL2 thiJ1 & $\mathrm{PAL}^{-} \mathrm{Thi}^{-}$ & Mizote et al. (1996) \\
\hline K3-9-101 & SN372L-3-9-10, $p d x L^{+}$nupC3146: : Tn10kan & $\mathrm{PIN}^{-} \mathrm{Thi}^{-}$ & Mizote et al. (1996) \\
\hline SN372L-K1 & SN372L-3-9-10, nupC3146::Tn10kan & $\mathrm{PAL}^{-} \mathrm{Thi}^{-}$ & SN372L-3-9-10 × p1 $k c(\mathrm{CAG} 18565)$ \\
\hline SN372L-3-T1 & SN372L-3 pdxL2 nupC3146:: Tn10kan & $\mathrm{PIN}^{-} \mathrm{Thi}^{-}$ & Mizote et al. (1996) \\
\hline NI500 & JC1552, thiD1 & Thi $^{-}$ & Imamura \& Nakayama (1981) \\
\hline NI500-T1 & N1500 pdxL2 nupC3146:: Tn10kan & Thi $^{-}$ & $\mathrm{NI} 500 \times \mathrm{P} 1 k c(\mathrm{SN} 372 \mathrm{~L}-\mathrm{K} 1) \mathbb{S}$ \\
\hline SN164L-1 & JC1552 thiA thiM1 & Thi ${ }^{-}$ & Mizote \& Nakayama (1989b) \\
\hline CAG18565 & nupC3146:: Tn10kan & & NIG \\
\hline $\mathrm{DH} 5 \alpha$ & $\begin{array}{l}\text { recA endA1 gyrA96 thi-1 bsdR17 supE44 } \\
\text { (lac)U169 ( } \phi 80 \text { acdM15) }\end{array}$ & & BRL \\
\hline HB101 & $\begin{array}{l}\text { hsdS20 recA13 ars-14 proA2 lacY1 galK2 } \\
\text { rpsL20 xyl-5 mtl-1 supE44 }\end{array}$ & & Maniatis et al. (1982) \\
\hline JM109 & 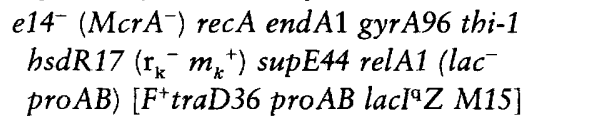 & & CGSC \\
\hline BL21 (DE3)(pLysS) & $\begin{array}{l}\text { E. coli B F- dem ompT hsdS }\left(\mathrm{r}_{\mathrm{B}}{ }^{-} \mathrm{m}_{\mathrm{B}}{ }^{-}\right) \\
\left.\text {gal-1(DE3)[pLsS Cam }{ }^{\mathrm{r}}\right]\end{array}$ & & Studier \& Moffatt (1986) \\
\hline \multicolumn{4}{|c|}{ 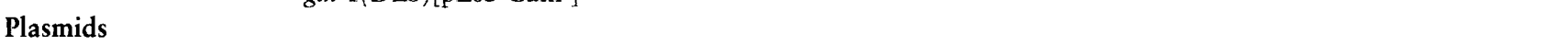 } \\
\hline pBR322 & E. coli vector, $\mathrm{Ap}^{\mathrm{r}} \mathrm{Tc}^{\mathrm{r}}$ & & Bolivar et al. (1977) \\
\hline pUC18 & E. coli vector, $\mathrm{Ap}^{\mathrm{r}}$ & & Yanisch-Perron et al. (1985) \\
\hline pET3a & E. coli vector, $\mathrm{Ap}^{\mathrm{r}}$ & & Rosenberg et al. (1987) \\
\hline pMT1282 & $\mathrm{Tra}^{+} \mathrm{Tp}^{\mathrm{r}} \mathrm{Su}^{\mathrm{r}} \mathrm{Tc} \mathrm{c}^{\mathrm{r}}, \mathrm{R} 388:: \operatorname{Tn} 1722$ & & Tsuda et al. (1989) \\
\hline pAM410 & A $6.9 \mathrm{~kb}$ EcoRV fragment in pBR322 & & This work \\
\hline
\end{tabular}

* Genetic nomenclature is as given by Berlyn et al. (1996).

†PIN ${ }^{-}$, strains requiring PIN or PAL at concentrations above $0 \cdot 1 \mu \mathrm{M}$ for their maximum growth; $\mathrm{PAL}^{-}$, strains capable of growing on PAL to the same extent as PIN $^{-}$strains, but incapable of growing on PIN below $0 \cdot 1 \mu \mathrm{M}$ and requiring PIN above $10 \mu \mathrm{M}$ for maximum growth; Thi ${ }^{-}$, strains requiring thiamin for growth.

‡CGSC, Coli Genetic Stock Center, Department of Biology 255 OML, Yale University, New Haven, CT, USA; NIG, National Institute of Genetics, Department of Microbiology, Mishima, Shizuoka, Japan.

$\$$ To introduce the $p d x L$ mutation $(51.65 \mathrm{~min})$ into NI500, we transduced nupC:: Tn10kan (51.75 min) from strain CAG18565 into SN372L-3-9-10 ( $p d x B p d x L$ thiJ) by P1-mediated transduction. Tn10kan transductants were first screened on minimal agar plates containing thiamin, PAL and kanamycin, and then $p d x L$ transductants were selected on plates containing thiamin and PIN. One of the transductants, SN372L-K1 was used as a donor to introduce the $p d x L$ mutation into NI500 and transductants were isolated on plates containing thiamin and kanamycin. Several transductants were assayed for HMP kinase activity in crude extracts and NI500-T1 was isolated that had neither thiamin-repressible (ThiJ) nor thiamin non-repressible (PdxL) HMP kinase.

the manufacturer. Gel-filtration chromatography of the purified enzyme $(50 \mu \mathrm{l})$ was performed using a column $(29.5 \times 1.2 \mathrm{~cm})$ packed with Sepharose $6 \mathrm{~B}$. Chromatography was performed at a flow rate of $0.8 \mathrm{ml} \mathrm{min}^{-1}$ in $20 \mathrm{mM}$ Tris $/ \mathrm{HCl}, \mathrm{pH} 7.5$, containing $0.2 \mathrm{M} \mathrm{NaCl}$ and $0.5 \mathrm{mM}$ DTT. The molecular mass of the protein was calibrated using proteins of standard molecular mass (New England Biolabs). Protein concentrations were determined using the Bradford method (1976).

Enzyme assay. Enzyme activity with crude extracts was measured as described previously (Nakayama \& Hayashi, 1972, 1979). When ThiD-overexpressing cells were used to purify ThiD, enzyme activity was measured with the reaction mixture in a final volume of $100 \mu$ l containing $0 \cdot 1 \mathrm{M}$ Tris $/ \mathrm{HCl}$, $\mathrm{pH} 7 \cdot 0,10 \mathrm{mM}$ ATP, $1.0 \mathrm{mM} \mathrm{MgCl}, 1 \mu$ protein preparation at a concentration of $1 \mathrm{mg}$ protein $\mathrm{ml}^{-1}$ and either $0.1 \mathrm{mM}$ HMP or HMP-P. After completion of the reaction at $37^{\circ} \mathrm{C}$, the reaction mixture was heated to $100^{\circ} \mathrm{C}$ for $5 \mathrm{~min}$ and centrifuged. The supernatant fraction was used to quantify the reaction products.

Chemicals. HMP was a gift from Takeda Chemical Industries, Osaka, Japan. HMP-P and HMP-PP were prepared from bromomethylpyrimidine according to the method of Lewin \& Brown (1961). PIN and alkaline phosphatase were purchased from Sigma.

Amino acid sequence analysis. The sequence of the first 10 residues of the purified ThiD protein was determined by an Applied Biosystems model 476A protein sequencer.

Nucleotide sequence analysis. The nucleotide sequences of the thiD and thiM genes have been submitted to DDBJ under the accession numbers D84200 and D88442, respectively. The DNASIS alignment program was used to align homologous $E$. coli and Salmonella typhimurium sequences. 


\section{RESULTS AND DISCUSSION}

\section{Characterization of a thiD-mutant strain, NI500}

E. coli strain NI500 is defective in thiamin-PP biosynthesis because of a mutation in thiD encoding HMPP kinase. NI500 had a wild-type level of HMP kinase activity, which could be due to HMP kinase (thiJ gene) and PAL kinase ( $p d x L$ gene) whereas SN372L-K1 ( $p d x L$ thiJ) had no HMP kinase activity (Table 2). To determine the role of ThiJ in NI500, we transduced $p d x L$ into this strain to obtain a thiD $p d x L$ double mutant, NI500-T1. The extract from NI500-T1 had no HMP kinase activity, irrespective of the growth conditions. We used two control strains, K3-9-101 ( $p d x L^{+}$ thiJ) and SN372L-3-T1 ( $p d x L$ thiJ $\left.^{+}\right)$. K3-9-101 cells contained HMP kinase activity even when grown with excess thiamin $(100 \mathrm{nM})$ due to the non-repressible $p d x L$ gene product. On the other hand, SN372L-3-T1 cells had the repressible HMP kinase activity due to the thiJ gene product. The results showing that NI500-T1 had no HMP kinase activity appeared to be in conflict with our previous conclusion that NI500 was missing only HMP-P kinase, encoded by thiD. Consideration of the present results together with the previous ones have led to the assumption that the thiD mutation carried by NI500 might be responsible for the loss of activities of HMP-P kinase together with the inactivation of HMP kinase and that the measured HMP kinase activity in the previous study might virtually all be due to PdxL.

\section{Cloning of a region containing thiD, this and thiM}

We have previously reported that the thiD, thiJ and thiM mutations are located around $46 \mathrm{~min}$ on the chromosome (Imamura \& Nakayama, 1981, Mizote \& Nakayama, 1989b, Mizote et al., 1996) which was covered by $8 \mathrm{~F} 4$ of an E. coli genomic library (Kohara et al., 1989). A $6.9 \mathrm{~kb}$ EcoRV fragment on $8 \mathrm{~F} 4$ was cloned into the EcoRV site of pBR322, and the resulting plasmid

Table 2. HMP kinase activity of NI500 and its $p d x L$ derivatives

\begin{tabular}{|c|c|c|}
\hline \multirow{2}{*}{$\begin{array}{l}\text { Strain (relevant genotype) } \\
\qquad \text { Thiamin concn }(\mathrm{nM}) \ldots\end{array}$} & \multicolumn{2}{|c|}{ HMP-P formed $\dagger$} \\
\hline & 2 & 100 \\
\hline SN372L-K1 ( $p d x L$ thiJ) & $<0.01$ & $<0.01$ \\
\hline NI500 (thiD $\left.p d x L^{+}\right)$ & $7 \cdot 12 \pm 0 \cdot 41$ & $8 \cdot 32 \pm 0 \cdot 27$ \\
\hline NI500-T1 (thiD pdxL) & $<0.01$ & $<0.01$ \\
\hline K3-9-101 $\left(p d x L^{+} t h i J\right) \ddagger$ & $6 \cdot 12 \pm 0 \cdot 21$ & $7 \cdot 56 \pm 0 \cdot 28$ \\
\hline SN372L-3-T1 ( $p d x L$ thiJ $\left.)^{+}\right) \neq$ & $6.26 \pm 0.46$ & $<0.01$ \\
\hline
\end{tabular}

† nmol HMP-P formed (mg protein $)^{-1} \mathrm{~h}^{-1}$. Extracts were prepared from cells grown on the indicated concentrations of thiamin. The reaction mixture contained $0.1 \mathrm{mM}$ HMP and crude cell-free extract $\left(6 \mathrm{mg}\right.$ protein $\left.\mathrm{ml}^{-1}\right)$, and was incubated at $37^{\circ} \mathrm{C}$ for $1 \mathrm{~h}$. Results are shown as the mean \pm SD of three independent experiments.

$\ddagger$ Mizote et al. (1996).

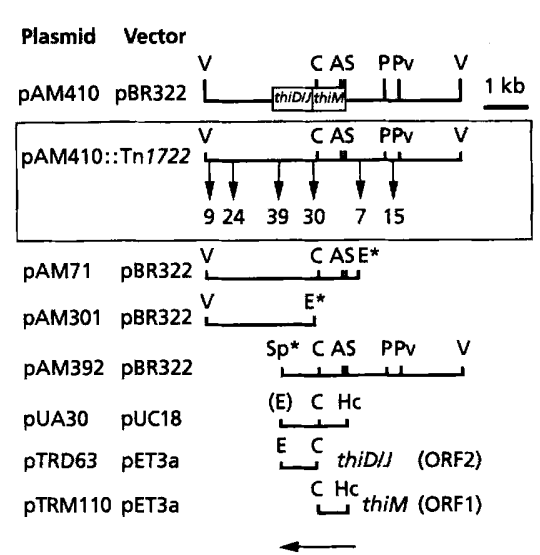

Complementation of: this thiD thim $+\quad+$

Fig. 2. Restriction maps of plasmids carrying this, thiD and thiM, and complementation of the this, thiD and thiM mutations. Coding sequences are indicated by open boxes. The numbers below the arrowheads in the pAM410::Tn1722 map show the insertion sites of Tn1722 in numerical order of their isolation. The restriction sites located within $\operatorname{Tn} 1722$ are indicated by asterisks. The complementation pattern of each of the subclones is shown on the right. + or - indicates the positive or negative growth response of transformants to supplementation of the following compounds in the minimal medium. When this cells were used as the host, PAL and HMP were added to the medium; for thiD cells, no supplements were added; and HET was added for the growth of thiM cells. Phenotypes of the strains carrying each of the thi mutations are listed in Table 1. The leftward arrow indicates the direction of transcription. Abbreviations for the restriction sites employed are as follows: A, ApaLl; E, EcoRI; C, Clal; Hc, Hincll; P, Pstl; Pv, Pvull; S, Sall; Sp, Sphl; V, EcoRV.

pAM410 (Fig. 2) was formed to complement the three thi mutations. Since appropriate restriction sites were not available in the $6.9 \mathrm{~kb}$ fragment, transposon $\mathrm{Tn} 1722$, which contains EcoRI and SphI sites, was randomly inserted into pAM410. Digestion of the resulting plasmids with EcoRI or $S p h I$ and subsequent self-ligation generated pAM71, pAM301 and pAM392. Both pAM71 and pAM392 complemented the thiJ, thiD and thiM mutations, indicating that the common $1.7 \mathrm{~kb}$ fragment on the two plasmids contained thiJ, thiD and thiM. The plasmid, pAM410:: Tn1722-39 was then digested with EcoRI and HincII and the resulting $1.7 \mathrm{~kb}$ fragment was blunt ended and subcloned into the HincII site of pUC18 to give pUA30. Detailed restriction analysis of the $1.7 \mathrm{~kb}$ fragment and comparison with the published physical map of the E. coli K-12 chromosome (Kohara et al., 1989) revealed that the fragment matched to the $2195 \mathrm{~kb}$ coordinate on the Kohara map.

\section{Nucleotide sequence analysis and cloning of thiM, this and thiD}

The nucleotide sequence of the $1.7 \mathrm{~kb}$ fragment has been deposited separately as thiD and thiM at DDBJ as D84200 and D88442, respectively. This fragment contains two ORFs, 708 bp ORF1 (235 amino acids) and 801 bp ORF2 (266 amino acids), encoding proteins with predicted molecular masses of 24378 and 28728 , respectively. The start codon of ORF2 overlapped with the 


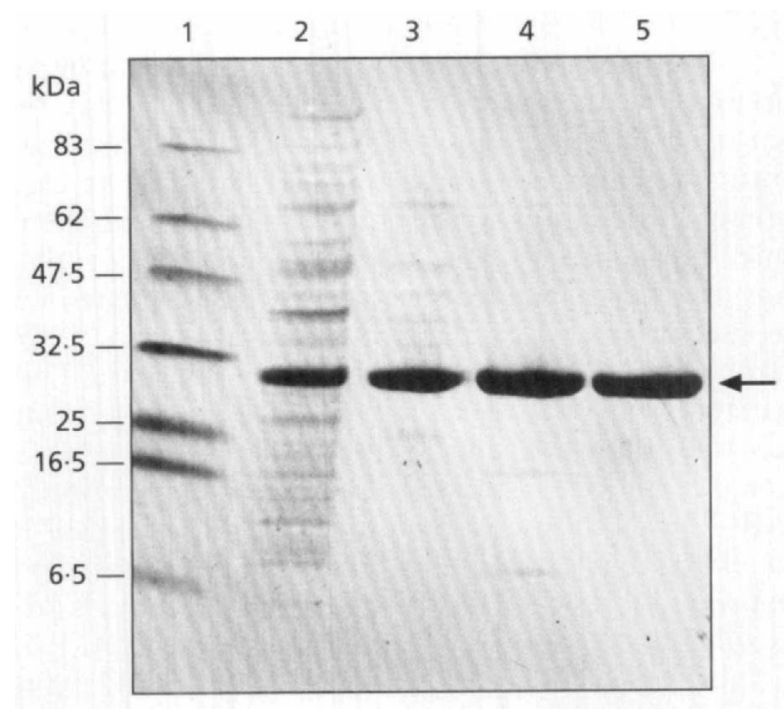

Fig. 3. Overexpression of ThiD and its purification. Overexpression of ThiD was performed as described in the text. The samples were separated by SDS-PAGE on a 10-20\% gradient Tris-Tricine gel and visualized by Coomassie blue staining. Lane 1, molecular mass markers; lane 2, crude extract from induced cells obtained by French pressing; lane 3, active fractions $(5 \mu \mathrm{g}$ protein) pooled after HiTrap $\mathrm{Q}$ column chromatography; lane 4 , active fractions $(5 \mu \mathrm{g}$ protein) pooled after IMAC; lane 5 , active preparation ( $5 \mu \mathrm{g}$ protein) from Mono $Q$ column chromatography. Molecular mass markers: maltose-binding protein- $\beta$-galactosidase $(83.0 \mathrm{kDa})$, glutamic dehydrogenase $(62.0 \mathrm{kDa})$, aldolase $(47.5 \mathrm{kDa})$, triosephosphate isomerase $(32.5 \mathrm{kDa}), \beta$-lactoglobulin $A(25.0 \mathrm{kDa})$, lysozyme $(16.5 \mathrm{kDa})$, aprotinin (6.5 kDa).

stop codon of ORF1. Each ORF was separately amplified by PCR. Each PCR product was, after insertion into the EcoRV site of pBluescript $\mathrm{KS}(+)$, excised by digestion with $N d e \mathrm{I}$ and $B a m \mathrm{HI}$ and cloned into $E$. coli expression vector pET3a to obtain pTRM110 and pTRD63 for ORF1 and ORF2, respectively. As shown in Fig. 2, pTRM110 complemented the thiM mutation, whereas pTRD63 complemented both the thiJ and thiD mutations.
The $1.7 \mathrm{~kb} E$. coli fragment showed very similar properties to that of $S$. typhimurium, where the thiM and thiD genes are organized as an operon (Petersen \& Downs, 1997). The two fragments exhibited high nucleotide-sequence identity $(63 \%)$. The lengths of $E$. coli ORF1 and ORF2 were identical to those of thiM and thiD, respectively, of $S$. typhimurium, and the amino acid sequences of the ThiD proteins from the two organisms showed $90 \%$ identity. The Shine-Dalgarno sequence for thiD was found in the upstream gene, thiM, suggesting that a similar regulatory mechanism operates for expression of the two thiMD operons.

In Saccharomyces cerevisiae, HET kinase and thiamin$P$ synthetase activities are specified by a bifunctional enzyme having two similar ATP-binding motifs (Nosaka et al., 1994). However, such an ATP-binding motif was not found in the sequence of ThiM in E. coli. Many ATP- and GTP-binding proteins contain a consensus sequence motif [AG] $\mathrm{X}_{4}$ GK[ST] (Walker et al., 1984). A sequence similar to this motif, GIQLDLKT, is found in the ThiD sequence starting at position 19 from the $\mathrm{N}$ terminus. Although the phosphorylation reaction of HMP appeared to occur by two steps, only one ATPbinding motif was found in ThiD. The two-step mechanism for phosphorylation is still unclear.

\section{Purification and characterization of the thiD/J product}

pTRD63, carrying thiD/J, was transformed into a host strain, E. coli BL21(DE3)(pLysS), and the thiD/J gene was overexpressed by incubation with IPTG for $2 \mathrm{~h}$. The uninduced cells contained no thiD/J gene product. After preparation of the crude extracts by French pressing of the cells, the $t h i D / J$ product, ThiD, was purified from the crude extract by three chromatography steps and the enzyme activities recovered from each purification step were measured (Fig. 3 and Table 3). HMP/HMP-P kinase eluted from the IMAC column as a broad peak centred at $35 \mathrm{mM}$ imidazole and from the Mono Q column as a sharp peak centred at $0.28 \mathrm{M}$ $\mathrm{NaCl}$. IMAC can be used to separate protein by means

\section{Table 3. Enzyme activity recovered from each purification step}

The reaction mixture containing $0.1 \mathrm{mM} \mathrm{HMP}$ and $10 \mu \mathrm{g}$ protein $\mathrm{ml}^{-1}$ was incubated at $37^{\circ} \mathrm{C}$ for $30 \mathrm{~min}$. Results are given in nmol phosphate ester formed (mg protein) ${ }^{-1} \mathrm{~min}^{-1}$ and are the mean \pm SD of three independent experiments.

\begin{tabular}{|c|c|c|c|c|c|c|}
\hline \multirow{2}{*}{$\begin{array}{l}\text { Purification } \\
\text { step }\end{array}$} & \multirow{2}{*}{$\begin{array}{l}\text { Vol. } \\
\text { (ml) }\end{array}$} & \multirow{2}{*}{$\begin{array}{l}\text { Total } \\
\text { protein } \\
(\mathrm{mg})\end{array}$} & \multicolumn{2}{|c|}{ Specific activity* } & \multirow[t]{2}{*}{$(\mathbf{a}) /(\mathbf{b})$} & \multirow{2}{*}{$\begin{array}{l}\text { Yield } \\
(\%)\end{array}$} \\
\hline & & & $\begin{array}{c}\text { HMP } \\
\text { kinase } \\
\text { (a) }\end{array}$ & $\begin{array}{c}\text { HMP-P } \\
\text { kinase } \\
\text { (b) }\end{array}$ & & \\
\hline Crude extract & $65 \cdot 1$ & $71 \cdot 0$ & $289 \pm 5$ & $189 \pm 2$ & 1.53 & 100 \\
\hline HiTrap Q & $15 \cdot 8$ & $30 \cdot 8$ & $264 \pm 7$ & $692 \pm 8$ & $0 \cdot 38$ & $84 \cdot 5$ \\
\hline IMAC & $11 \cdot 9$ & $20 \cdot 8$ & $302 \pm 6$ & $798 \pm 12$ & $0 \cdot 38$ & $66 \cdot 3$ \\
\hline Mono Q & $5 \cdot 8$ & $15 \cdot 6$ & $329 \pm 2$ & $843 \pm 4$ & $0 \cdot 39$ & 53.6 \\
\hline
\end{tabular}

$*$ nmol (mg protein $)^{-1} \min ^{-1}$. 

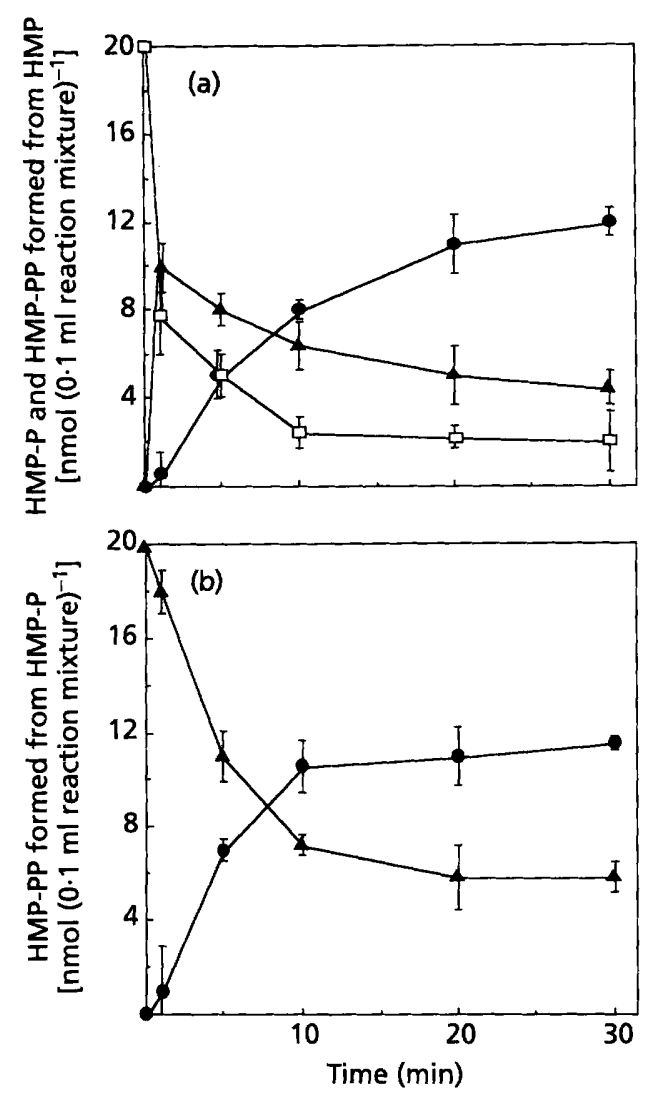

Fig. 4. Formation of HMP-P and HMP-PP from HMP (a) and HMP-PP from HMP-P (b) by purified ThiD. Results shown are the means $\pm S D$ of three independent experiments. The remaining amount of HMP in the former case and HMP-P in the latter case are also shown. The reaction mixture and the assay system are described in the text. HMP was not detected when HMP-P was used as the substrate. The amounts of HMP $(\square), \operatorname{HMP}-P(\boldsymbol{\Delta})$ and HMP-PP (O) in the reaction mixture are shown.

of an interaction between matrix-bound metal and surface histidine residues. This method is often used for purification in the protein fused with histidine. Successful purification of the non-fusion protein might be ascribed to the presence of three histidine residues at the C-terminus of ThiD (HHFHAWW). The SDS-PAGE analysis revealed that the purified ThiD has a molecular mass of $27.5 \mathrm{kDa}$ (Fig. 3). IEF-PAGE of the purified protein gave a $\mathrm{pl}$ of $5 \cdot 6$ (data not shown), which was in good agreement with the value of 5.7 deduced from the protein sequence. Gel-filtration chromatography gave a molecular mass of $31 \mathrm{kDa}$, indicating that ThiD exists as a monomer in solution. The actual amino acid sequence that was determined agreed with that predicted from the nucleotide sequence.

\section{Phosphorylation of HMP and HMP-P by ThiD}

The time courses of the formation of HMP-P and HMPPP from HMP and of HMP-PP from HMP-P were measured in the reaction mixture containing ATP (Fig. 4a). When HMP was used as a substrate, it decreased rapidly with the concomitant formation of HMP-P and HMP-PP. The HMP-P concentration peaked 1 min after initiation of the reaction, and the HMP-P was then converted to HMP-PP. When HMP-P was used as a substrate, it was converted to HMP-PP and the formation of HMP could not be detected (Fig. 4b). Under the same experimental conditions, ThiD did not phosphorylate PIN (data not shown), which contrasted with the specificity of PdxL (Mizote \& Nakayama, 1989a; Mizote et al., 1996). The time-course study of the ThiDmediated phosphate ester formation from HMP clearly indicated that the enzyme catalyses two successive phosphorylation reactions. Transient formation of HMP-P was followed by accumulation of HMP-PP, suggesting that HMP-P is a dissociable intermediate in the production of HMP-PP from HMP. Although PdxL phosphorylated both HMP and PAL derivatives (Mizote \& Nakayama, 1989a; Mizote et al., 1996), ThiD did not phosphorylate PAL derivatives (data not shown). These results lead us to conclude that the substrate recognition of this enzyme is more discriminating than that of $\mathrm{PdxL}$. As the purified ThiD protein of E. coli phosphorylated HMP to form both HMP-P and HMP-PP, and also HMP-P to form HMP-PP, there is a possibility that ThiD of S. typhimurium, which has $90 \%$ identity with E. coli ThiD, might also be a bifunctional enzyme having the same properties.

The results presented here indicate that the thiD mutant, NI500, which had lost both HMP and HMP-P kinase activities, and that the thiJ mutant, SN372L-3-9-10, acquired mutations in the same, thiD/J gene. Further experiments will be needed to characterize the thiD and thij mutations at the nucleotide level.

\section{ACKNOWLEDGEMENTS}

We thank Dr Y. Takahashi, Perkin Elmer Japan, for DNA sequencing. We greatly acknowledge Dr I. F. Connerton, Institute of Food Research, UK, for his kind suggestions on the molecular biological aspects of this study.

\section{REFERENCES}

Backstrom, A. D., Austin, R., McMordie, S. \& Begley, T. P. (1995). Biosynthesis of thiamin I: the function of the thiE gene product. $J$ Am Chem Soc 117, 2351-2352.

Bradford, M. M. (1976). A rapid and sensitive method for the quantitation of microgram quantities of protein utilizing the principle of protein-dye binding. Anal Biochem 72, 248-254.

Berlyn, M. K. B., Low, K. B. \& Rudd, K. E. (1996). Linkage map of Escherichia coli K-12, edition 9. In Escherichia coli and Salmonella: Cellular and Molecular Biology, 2nd edn. Edited by F. C. Neidhardt and others. Washington, DC: American Society for Microbiology.

Bolivar, F., Rodriguez, R. L., Greens, P. J., Betlach, M. C., Heyneker, H. L., Boyer, H. W., Crosa, J. H. \& Falkow, S. (1977). Construction and characterization of new cloning vehicles. II. A multipurpose cloning system. Gene 2, 95-113.

Don, R. H., Cox, P. T., Wainwrite, B. J., Baker, K. \& Mattik, J. S. (1991). 'Touchdown'PCR to circumvent spurious priming during gene amplification. Nucleic Acids Res 19, 4008. 
Horn, P. B. V., Backstrom A. D., Stewart V. \& Begley, T. P. (1993). Structural genes for thiamine biosynthetic enzymes (thiCEFGH) in Escherichia coli $\mathrm{K}-12$. J Bacteriol 175, 982-992.

Imamura, N. \& Nakayama, H. (1981). thiD locus of Escherichia coli. Experientia 37, 1265-1266.

Kawasaki, T., Nakata, T. \& Nose, Y. (1968). Genetic mapping with a thiamine-requiring auxotroph of Escherichia coli $\mathrm{K}-12$ defective in thiamine phosphate pyrophosphorylase. I Bacteriol 95, 1483-1485.

Kohara, Y., Akiyama, K. \& Isono, K. (1989). The physical map of the whole $E$. coli chromosome: application of a new strategy for rapid analysis and sorting of a large genomic library. Cell 50, 495-508.

Lennox, E. S. (1955). Transduction of linked genetic characters of the host by bacteriophage P1. Virology 1, 190-206.

Lewin, L. M. \& Brown, G. M. (1961). The biosynthesis of thiamine. III. Mechanism of enzymatic formation of the pyrophosphate ester of 2-methyl-4-amino-5-hydroxymethylpyrimidine. J Biol Chem 236, 2768-2771.

Low, K. B. (1973). Rapid mapping of conditional and auxotrophic mutations in Escherichia coli K-12. J Bacteriol 113, 798-812.

Maniatis, T., Fritsch, E. F. \& Sambrook, J. (1982). Molecular Cloning: a Laboratory Manual. Cold Spring Harbor, NY: Cold Spring Harbor Laboratory.

Mizote, T. \& Nakayama, H. (1989a). Purification and properties of hydroxymethylpyrimidine kinase from Escherichia coli. Biochim Biophys Acta 991, 109-113.

Mizote, T. \& Nakayama, H. (1989b). The thiM locus and its relation to phosphorylation of hydroxyethylthiazole in Escherichia coli. J Bacteriol 171, 3228-3232.

Mizote, T., Tsuda, M., Nakazawa, T. \& Nakayama, H. (1996). The thij locus and its relation to phosphorylation of hydroxymethylpyrimidine in Escherichia coli. Microbiology 142, 2969-2974.

Nakayama, H. (1990). Genetic analysis of thiamin pyrophosphate biosynthesis in Escherichia coli. Vitamins 64, 619-632.

Nakayama, H. \& Hayashi, R. (1972). Biosynthetic pathway of thiamine pyrophosphate: a special reference to the thiamine monophosphate-requiring mutant and the thiamine pyrophosphate-requiring mutant of Escherichia coli. J Bacteriol 112, 1118-1126.
Nakayama, H. \& Hayashi, R. (1979). Isolation and characterization of Escherichia coli mutants auxotrophic for thiamine phosphates. Methods Enzymol 62, 94-101.

Nosaka, K., Nishimura, H., Kawasaki, Y., Tsujihara, T. \& Iwashima, A. (1994). Isolation and characterization of the THI8 gene encoding a bifunctional thiamin-phosphate pyrophospholyase/ hydroxyethylthiazole kinase from Saccharomyces cerevisiae. J Biol Chem 269, 30510-31506.

Petersen, L. A. \& Downs, D. M. (1997). Identification and characterization of an operon in Salmonella typhimurium involved in thiamin biosynthesis. J Bacteriol 179, 4894-4900.

Rosenberg, A. H., Lade, B. N., Chui, D., Lin, S.-D., Dunn, J. J. \& Studier, F. W. (1987). Vectors for selective expression of cloned DNAs by T7 RNA polymerase. Gene 56, 125-135.

Sambrook, J., Fritsch, E. F. \& Maniatis, T. (1989). Molecular Cloning: a Laboratory Manual, 2nd edn. Cold Spring Harbor, NY: Cold Spring Harbor Laboratory.

Studier, F. W. \& Moffatt, B. A. (1986). Use of bacteriophage T7 RNA polymerase to direct selective high-level expression of cloned genes. J Mol Biol 189, 113-130.

Taylor, A. L. \& Trotter, C. D. (1967). Revised linkage map of Escherichia coli. Bacteriol Rev 31, 332-353.

Tsuda, M. \& lino, T. (1987). Genetic analysis of a transposon carrying toluene degrading genes on a TOL plasmid pWW0. Mol Gen Genet 210, 270-276.

Tsuda, M., Minegishi, K. \& lino, T. (1989). Toluene transposons Tn4651 and Tn4653 are class II transposons. J Bacteriol 171, 1386-1393.

Ubben, D. \& Schmit, R. (1986). Tn1721 derivatives for transposon mutagenesis, restriction mapping and nucleotide sequence analysis. Gene 41, 145-152.

Walker, J. E., Saraste, M. \& Gay, N. J. (1984). The unc operon nucleotide sequence, regulation and structure of ATP-synthase. Biochim Biophys Acta 768, 164-200.

Yanisch-Perron, C., Vieira, J. \& Messing, J. (1985). Improved M13 phage cloning vectors and host strains: nucleotide sequences of the M13mp18 and pUC19 vectors. Gene 33, 103-119.

Received 20 July 1998; revised 14 October 1998; accepted 6 November 1998. 